УДК 577.21:636.082, DOI 10.31210/visnyk2018.04.20

(C) 2018

Балацький В. М., доктор сільськогосподарських наук,

Вовк В. О., кандидат сільськогосподарських наук,

Буслик Т. В., кандидат біологічних наук,

Ільченко М. О., кандидат сільськогосподарських наук, Олійниченко $\epsilon$. К., аспірант

(науковий керівник - доктор сільськогосподарських наук В. М. Балаиький)

Інститут свинарства і агропромислового виробництва НААН

\title{
ГЕНЕТИЧНИЙ ТА АСОЦІАТИВНИЙ АНАЛІЗ ОДНОНУКЛЕОТИДНОГО ПОЛІМОРФІЗМУ G.22 G>C У ГЕНІ КАТЕПСИНУ F СВИНЕЙ РІЗНИХ ПОРІД
}

\section{Рецензент - доктор сільськогосподарських наук М. Д. Березовський}

\begin{abstract}
Визначено генетичну структуру порід свиней велика біла, полтавська м'ясна, велика чорна і миргородська за геном катепсину F (CTSF g.22 G>C SNP), встановлено основні популячійні параметри. В усіх породах генетичний маркер характеризувався поліморфізмом при переважанні за частотою алеля g.22C. Рівень інформативності CTSF g.22 G>C SNP виявлено на оптимальному для асоціативного аналізу рівні $(P I C=0,358-0,375)$, щзо дозволяе здійснювати у досліджених субпопулячіях порід пошук зв'язків маркера з ознаками продуктивності свиней. У субпопуляиії свиней великої білої породи української селекції проведено аналіз зв'язку генетичного маркера CTSF g.22 G>C SNP з показниками продуктивності тварин: віком досягнення живої маси 100 кг, товщииною шпику на рівні 6-7-го ребра, 10-го ребра, в області крижів і середньодобовим приростом маси та селекиійним індексом. Встановлено тенденцію до асоціаиії зазначеного генетичного маркера з віком досягнення тваринами живої маси 100 кг (p=0,07).
\end{abstract}

Ключові слова: свині, породи, SNP, генетична структура, ген катепсину $F$

Постановка проблеми. Останнім часом племінна робота у свинарстві все частіше грунтується на застосуванні технології маркерасоційованої селекції (MAS, marker-assisted selection), яка передбачає генотипування особин за локусами, що контролюють господарські ознаки, і використання отриманої молекулярної інформації для оцінки генотипів, добору і підбору тварин.

Встановлено велику кількість генівкандидатів, що належать до таких локусів (локуси кількісних ознак, QTL - quantitative traits loci), які впливають на репродуктивні, відгодівельні і м'ясні якості свиней. Але серед них відомо не так багато генів і відповідних ДНК маркерів, які 3 точки зору їх інформативності і сили асоціації 3 ознаками, можна ефективно використовувати у практиці селекційної роботи [2, 11].
Аналіз останніх досліджень і публікацій, у яких започатковано розв'язання проблеми. Ген катепсину F (CTSF) у свиней картований на хромосомі 2(SSC2) p14-p17 і складається 312 екзонів та 11 інтронів. Продуктом його експрессії є білок, який містить 474 амінокислотних залишка [6]. За фізіологічною функцією цього білка та локалізацією гену у межах QTL-регіону геному свині, що відповідає за м'ясні якості та накопичення жиру [9], його віднесено до кандидатних генів. Встановлено, що поліморфізм гену катепсину $\mathrm{F}$ відіграє суттєву роль у детермінації економічно важливих ознак свиней: середньодобового приросту живої маси тварин, відсотка пісного м'яса в туші та товщини хребтового сала. Зокрема, у роботах V. Russo показано значну асоціацію поліморфізму CTSF g.22 G>C SNP iз середньодобовим приростом та товщиною хребтового сала свиней породи італійська велика біла $[9,10]$. Зазначений поліморфізм CTSF обумовлений однонуклеотидною заміною $\mathrm{G}$ на $\mathrm{C}$ (rs1113132904) [6], що у свою чергу призводить до заміни в поліпептидному ланцюзі фермента катепсину F глутамінової кислоти на аспарагінову. Свині з генотипом g.22 CC гену катепсину F характеризувалися підвищеними показниками росту та меншою жирністю м'яса туші [9].

Для низки порід свиней, що розводять в Україні, визначено генетичну структуру за генами катепсинів CTSS, CTSL, CTSB, CTSK оцінено інформативність і можливість використання відповідних генетичних маркерів у MAS, встановлено їх асоціативні зв'язки з окремими ознаками продуктивності свиней великої білої породи [1, 4]. Подібна інформація щодо гену катепсину $\mathrm{F}$ відсутня і першим кроком щодо оцінки можливості його використання у MAS $\epsilon$ аналіз генетичної структури порід.

Мета роботи:

1) визначити генетичну структуру порід сви- 


\section{СІЛЬСЬКЕ ГОСПОДАРСТВО. ТВАРИННИЦТВО}

ней велика біла, миргородська, велика чорна i полтавська м'ясна за геном катепсину F (g.22 $\mathrm{G}>\mathrm{C} \mathrm{SNP})$, оцінити поліморфізм і інформативність генетичного маркеру для подальшого використання в асоціативних дослідженнях і маркер-асоційованій селекції;

2) дослідити асоціативні зв'язки генетичного маркера CTSF g.22 G>C SNP 3 окремими продуктивними ознаками свиней великої білої породи української селекції.

Завдання дослідження - дати оцінку доцільності використання генетичному маркеру CTSF g.22 G>C в подальших асоціативних досліджень та його використанню в інших породах.

Матеріали і методи досліджень. Тварини, що використовувались у дослідженнях, були перевірені на мутацію с.1843 СТ у гені ріанодінового рецептора 1, пов'язану з дефектами м'яса [3]. Всі тварини мали генотип $\mathrm{CC}$, що свідчить про відсутність мутантного аллеля.

Товщина шпику вимірювалася переносними цифровим «Renco Lean-Meater» (США, Renco Corporation) у трьох точках.

1. Товщина шпику на рівні 10-го ребра, мм (перерахунок на вагу 100 кг);

2. Товщина шпику на рівні 6-7-го ребра, мм (перерахунок на вагу 100 кг);

3. Товщина шпику на рівні крижів, мм (перерахунок на вагу 100 кг).

Зразки біологічного матеріалу для виділення ДНК відбирали від основного поголів'я племінних стад порід велика біла (ВБ, племзавод ДГ Степне, $\mathrm{n}=102)$, миргородська (M, племзавод ім. Декабристів, $\mathrm{n}=50)$, велика чорна (ВЧ, ТОВ «Маяк», n=50) та полтавська м'ясна (ПМ, ТОВ «племзавод «Біловодський», $\mathrm{n}=50)$.

ДНК із зразків м’яса тварин виділяли за допомогою комплекту реагентів «ДНК-сорб-В» (ИнтерЛабСервис, РФ) згідно інструкції.

Типування за SNP CTFS g. 22 G $>$ C проводили методом ПЛР-ПДРФ [4].

Для ампліфікації поліморфної ділянки гену у ПЛР використовували праймери наступної структури прямий

5/AGGGAGGGCTGGAGACGGAGTA-3/ та зворотній 5/-TCATTCTGGCTCAGCTCCAC-3/.

Рестрикцію продуктів ПЛР здійснювали за допомогою ендонуклеази RsaI відповідно до peкомендацій виробника (Thermo SCIENTIFIC, Литва).

Фрагменти рестрикції розділяли у 8 \% поліакриламідному гелі. Візуалізацію електрофореграм після фарбування гелю у бромистому етидії проводили на трансілюмінаторі в УФ світлі.
Частоти алелей і генотипів, рівні гетерозиготності Но (гетерозиготність, що спостерігається) і Не (очікувана гетерозиготність) були обчислені за використання програмного забезпечення і методики, описаної GenALEX6.0 [10], індекс інформаційного змісту поліморфізму (PIC - polymorphic information content) - PIC калькулятора [8]. Відхилення фактичного розподілу генотипів від рівноважного визначеного за формулою Гарді-Вайнберга статистично оцінено за використання критерію $\chi 2$.

Асоціаціативні зв'язки між генотипами та показниками досліджувалися за допомогою однофакторного дисперсійного аналізу (ANOVA) за використання пакетів прикладних програм Microsoft Excel 2007.

Результати дослідження. Результати дослідження генетичної структури порід свиней велика біла, миргородська, велика чорна і полтавська м'ясна за геном катепсина F (g.22 G>C SNP) представлені в таблиці 1.

В усіх досліджуваних вибірках свиней виявлено присутність як алелю g. $22 \mathrm{G}$, так і алелю g.22C, суттєвих міжпородних відмінностей не встановлено (табл. 1). Щодо розподілу генотипів, більшість тварин виявилася носіями гетерозиготного генотипу g.22CG ВБ $(0,47)$, ПМ $(0,52)$, М (0,52), ВЧ $(0,47)$, за присутності незначної кількості гомозиготних тварин g.22СС ПМ $(0,36)$, М $(0,34)$, ВЧ $(0,28)$, ВБ $(0,29)$. У той же час кількість особин гомозиготного генотипу g. $22 \mathrm{GG}$ ВБ $(0,29)$, ПМ $(0,12)$, М $(0,1)$, ВЧ $(0,14)$ було виявлено у значно меншій кількості. В усіх субпопуляціях спостерігалося незначне переважання фактичної частоти гетерозиготних генотипів над їх очікуваною частотою, що, у свою чергу, відбилося на значеннях індекса фіксації Райта. Відхилення розподілу генотипів від розрахованого за формулою Гарді-Вайнберга виявилося незначним $\mathrm{i}$ не носило достовірного характеру ВБ $(\chi 2=0,315), \Pi \mathrm{M}\left(\chi^{2}=0,536\right), \mathrm{M}(\chi 2=0,660)$, ВЧ $(\chi 2=0,556)$. Це вказувало на генетичну збалансованість досліджених субпопуляцій тварин за локусом CTFS, поліморфізм якого визначався за генетичним маркером g.22 G>C, а отже на відсутність селекційного тиску на нього.

Дані, отримані у результаті популяційного аналізу, дали змогу оцінити інформативність генетичного маркеру CTSF g.22 G>C SNP у досліджуваних породах.

Таке оцінювання було проведено шляхом розрахунку інформаційного змісту поліморфізму маркера. 


\section{1. Генетична структура субпопуляції свиней за однонуклеотидним поліморфізмом g.22 $G>C$ гену катепсину $F$}

\begin{tabular}{|c|c|c|c|c|c|c|c|c|c|c|}
\hline \multirow[t]{2}{*}{ Порода } & \multirow[t]{2}{*}{ Генотип } & \multirow[t]{2}{*}{$\mathrm{N}$} & \multirow[t]{2}{*}{$\begin{array}{c}\text { Частота } \\
\text { генотипів }\end{array}$} & \multicolumn{2}{|c|}{$\begin{array}{l}\text { Частота } \\
\text { аллелів }\end{array}$} & \multirow[t]{2}{*}{$\mathrm{H}_{\mathrm{o}}{ }^{\mathrm{a}}$} & \multirow[t]{2}{*}{$\mathrm{H}_{\mathrm{e}}^{\mathrm{b}}$} & \multirow[t]{2}{*}{$\mathrm{F}_{\text {is }}$} & \multirow[t]{2}{*}{$\chi^{2}$} & \multirow[t]{2}{*}{$\mathrm{PIC}^{\mathrm{c}}$} \\
\hline & & & & g.22C & g. $22 \mathrm{G}$ & & & & & \\
\hline \multirow{3}{*}{ ПМ } & GG & 6 & $0,12 / 0,15$ & \multirow{3}{*}{0,63} & \multirow{3}{*}{0,37} & \multirow{3}{*}{0,52} & \multirow{3}{*}{0,47} & \multirow{3}{*}{$-0,104$} & \multirow{3}{*}{0,536} & \multirow{3}{*}{0,358} \\
\hline & GC & 26 & $0,52 / 0,47$ & & & & & & & \\
\hline & $\mathrm{CC}$ & 18 & $0,36 / 0,38$ & & & & & & & \\
\hline \multirow{3}{*}{ ВЧ } & GG & 5 & $0,1 / 0,17$ & \multirow{3}{*}{0,59} & \multirow{3}{*}{0,41} & \multirow{3}{*}{0,62} & \multirow{3}{*}{0,48} & \multirow{3}{*}{$-0,282$} & \multirow{3}{*}{3,963} & \multirow{3}{*}{0,367} \\
\hline & $\mathrm{GC}$ & 31 & $0,62 / 0,48$ & & & & & & & \\
\hline & $\mathrm{CC}$ & 14 & $0,28 / 0,34$ & & & & & & & \\
\hline \multirow{3}{*}{ M } & GG & 7 & $0,14 / 0,16$ & \multirow{3}{*}{0,59} & \multirow{3}{*}{0,41} & \multirow{3}{*}{0,52} & \multirow{3}{*}{0,48} & \multirow{3}{*}{$-0,282$} & \multirow{3}{*}{0,347} & \multirow{3}{*}{0,367} \\
\hline & $\mathrm{GC}$ & 26 & $0,52 / 0,48$ & & & & & & & \\
\hline & $\mathrm{CC}$ & 17 & $0,34 / 0,36$ & & & & & & & \\
\hline \multirow{3}{*}{ ВБ } & GG & 30 & $0,29 / 0,28$ & \multirow{3}{*}{0,53} & \multirow{3}{*}{0,47} & & & & & \\
\hline & $\mathrm{CG}$ & 48 & $0,47 / 0,5$ & & & 0,47 & 0,50 & 0,000 & 0,315 & 0,371 \\
\hline & $\mathrm{CC}$ & 24 & $0,24 / 0,22$ & & & & & & & \\
\hline
\end{tabular}

Примітка: $\mathrm{n}$ - кількість тварин у вибірці, $\mathrm{H}_{\mathrm{o}}$ - фактична гетерозиготність, $\mathrm{H}_{\mathrm{e}}$ - очікувана гетерозиготність, $\mathrm{F}_{\text {is }}$ - індекс фіксації Райта, PIC - інформаційний зміст поліморфізму, $\chi^{2}$-значення критерію.

Середній рівень PIC $(0,25-0,75)$ є оптимальним для пошуку асоціації певного генетичного маркера 3 ознаками продуктивності в даній популяції $\mathrm{i}$ сприятливим щодо перспективи селекції з використанням молекулярної інформації за даним маркером. Низький (менш як 0,25) і високий (більш як $0,75)$ рівні PIC не є бажаними для асоціативних досліджень [6]. Для діалельних поліморфних генетичних систем максимальний рівень PIC $-0,375$. Щодо генетичного маркера CTSF g.22 G>C SNP, інформаційний зміст його поліморфізму в усіх субпопуляціях полтавської м'ясної, української великої білої, миргородської, великої чорної був на оптимальному для проведення асоціативних досліджень рівні (PIC=0,358-0,375). Результати асоціативних досліджень представлені в таблиці 2.

Статистично достовірних зв'язків генетичного маркера CTSF g.22 G>C SNP 3 досліджуваними ознаками продуктивності не виявлено. Встановлено лише тенденцію до його асоціації з віком досягнення тваринами живої маси 100 кг асоціації. Свині з генотипом GC характеризувалися більшим віком досягнення 100 кг у порівнянні з тваринами 3 генотипом $\mathrm{GG}(\mathrm{p}=0,07)$.

\section{Висновки:}

1. У породах свиней миргородська, велика біла, велика чорна і полтавська м'ясна генетичний маркер CTSF g.22 C G характеризувався переважанням алеля g. $22 \mathrm{C}$ за частотою. Не виявлено відхилення у розподілі CTSF-генотипів від збалансованого, визначеного за формулою Гарді-Вайнберга.

2. Рівень інформативності генетичного маркеру CTSF g.22 G>C SNP в усіх породах був на оптимальному для асоціативних досліджень рівні (PIC= 0,358-0,375), що дозволяє проводити пошук зв'язків маркера 3 ознаками продуктивності свиней.

3. Встановлено тенденцію до асоціації генетичного маркера CTSF g.22 G>C SNP 3 віком досягнення тваринами живої маси 100 кг $(\mathrm{p}=0,07)$.

4. Перспективи досліджень. Досліджувані популяції свиней порід полтавська м'ясна, миргородська, велика чорна, велика біла порода української селекції будуть використані для асоціативних досліджень з метою пошуку зв'язку маркерів з ознаками продуктивності свиней і впровадження маркер-асоційованної селекції. 
СІЛЬСЬКЕ ГОСПОДАРСТВО. ТВАРИННИЦТВО

\section{2. Асоціація між різними частотами алелей SNP CTSF g.22 G>C з продуктивними якостями} великої білої породи свиней украӥнської селекції.

\begin{tabular}{|c|c|c|c|c|c|c|}
\hline \multirow{2}{*}{ Продуктивні якості } & \multicolumn{3}{|c|}{ Генотипи CTSF SNP g.22 } & \multicolumn{3}{|c|}{$\mathrm{p}$} \\
\hline & $22^{\mathrm{GC}}$ & $22^{\mathrm{GG}}$ & $22^{\mathrm{CC}}$ & $\mathrm{GC} / \mathrm{GG}$ & $\mathrm{GG} / \mathrm{CC}$ & $\mathrm{GC} / \mathrm{CC}$ \\
\hline $\begin{array}{l}\text { Вік досягнення живої } \\
\text { маси } 100 \text { кг (днів) }\end{array}$ & $199,92 \pm 2,66$ & $193,47 \pm 2,29$ & $198,36 \pm 4,36$ & 0,07 & 0,32 & 0,76 \\
\hline $\begin{array}{l}\text { Шпик на рівні } 10-г о \text { ре- } \\
\text { бра, мм (розрахована на } \\
100 \text { кг живої ваги) }\end{array}$ & $18,90 \pm 0,54$ & $19,44 \pm 0,61$ & $18,86 \pm 1,01$ & 0,51 & 0,62 & 0,97 \\
\hline $\begin{array}{l}\text { Шпик на рівні 6-7-го } \\
\text { ребра, мм (розрахована } \\
\text { на } 100 \text { кг живої ваги) }\end{array}$ & $24,00 \pm 0,68$ & $24,07 \pm 0,72$ & $23,89 \pm 1,06$ & 0,94 & 0,88 & 0,93 \\
\hline $\begin{array}{l}\text { Товщина шпику на рівні } \\
\text { крижів, мм (розрахована } \\
\text { на } 100 \text { кг живої ваги) } \\
\end{array}$ & $19,71 \pm 0,60$ & $19,96 \pm 0,75$ & $20,03 \pm 0,96$ & 0,79 & 0,96 & 0,78 \\
\hline $\begin{array}{l}\text { Добовий приріст ваги, г } \\
\text { (розрахована на } 100 \text { кг } \\
\text { живої ваги) }\end{array}$ & $504,68 \pm 6,79$ & $519,26 \pm 6,07$ & $509,30 \pm 10,95$ & 0,11 & 0,42 & 0,72 \\
\hline
\end{tabular}

Примітка: $\mathrm{p}$ - рівень статистичної значущості різниці показника між групами; $\mathrm{p} \leq 0,06-0,09$ - тенденція до зміни показника за критерієм t Стьюдента; $\mathrm{p} \leq 0,05 \ldots \mathrm{p} \leq 0,001$ - значуща зміна за критерієм $\mathrm{t}$ Стьюдента.

\section{БІБЛІОГРАФІЯ}

1. Balatsky V.N. Sequence variation in the cathepsin B (CTSB), L (CTSL), S (CTSS) and K (CTSK) genes in Ukrainian pig breeds / V.N. Balatsky, K. F. Pochernyaev, T. V. Buslyk, O.S. Dykan, S. N. Korinnyi, R. Pena, O. Doran // Global J. Anim. Breed. Genet., - 2015. - Vol. 3 (3), - P. 117-124.

2. Cui $Y$. Mapping quantitative trait loci in selected breeding populations: A segregation distortion approach / Y. Cui, F. Zhang, J. Xu, Z. Li, S. Xu // Heredity (Edinb). - 2015. - №115(6). P. 538-546.

3. Dan J. Nonneman, Tami Brown-Brandl, Shuna A., Jones, Ralph T. Wiedmann, Gary A., Rohrer A defect in dystrophin causes a novel porcine stress syndrome // BMC Genomics. - 2012. - Vol. 13. P. 233-238.

4. Hao L. L. Single nucleotide polymorphism analysis of exons 3 and 4 of IGF-1 gene in pigs / L. L. Hao, H. Yu, Y. Zhang, S. C. Sun, S. C. Liu, Y. Z. Zeng // Genet. Mol. Res. - 2011. - Vol. 10. P. 1689-95.

5. NCBI RS database, [Електронний ресурс]: [База даних]. - Електронні дані. URL: https://www.ncbi.nlm.nih.gov/SNP/snp_ref (24.03.2018).

6. NCBI [Електронний ресурс]. [База даних]. -
Електр. дані. URL: https://www.ncbi.nlm.nih.gov/ gene/100520004 ( дата звернення 25.11.2017).

7. Peakall $R$. GENALEX 6: genetic analysis in Excel. Population genetic software for teaching and research / R. Peakall, P. E. Smouse // Molecular Ecology Notes. - 2006. - Vol. 6. - P. 288-295.

8. PIC calculator [Elektronniy resurs]. [Internetprograma]. URL:http://www.liv.ac.uk/ kempsj/pic. $\mathrm{html}$ (дата звернення 05.09.2018).

9. Russo $V$. Association of the CTSB,CTSF and CSTB genes with growth, carcass and meat quality traits in heavy pigs / V. Russo, R. Davoli, L. Costa Nanni, L. Fontanesi, C. Baiocco, L. Buttazzoni, S. Galli, R.Virgili // Italian Journal of Animal Science. - 1998. - Vol. 2. - P. 67-69.

10. Russo $V$. Linkage mapping of the porcine cathepsin F (CTSF) gene close to the QTL regions For meat and Fat deposition traits on pig chromosome 2 / Russo, L. Fontanesi, R. Davoli, S. Galli // Anim. Genet. - 2004. - Vol. 35. - P. 155157.

11. Williams J.L. The use of marker-assisted selection in animal breeding and biotechnology // Rev Sci Tech. - 2005. - Vol. 24. - P. 379-91. 


\section{ANNOTATION}

Balatskyi V. M., Vovk V.O., Buslyk T. V., Ilchenko M. O., Oliinychenko Ye. K. The geneticassociated analysis of g. $22 \mathrm{G}>\mathrm{C}$ single-nucleotide polymorphism in $\mathrm{F}$ cathepsin gene of different pig breeds.

Lately, stud pig breeding has increasingly been getting based on the use of marker-associated selection (MAS) technology, which involves the genotyping of individuals according to the loci controlling economic characteristics and the use of the received molecular information for evaluating the genotypes of diferentt animal selection. A large number of candidate genes belonging to such loci (QTL - quantitative traits loci) that influence the reproductive, fattening and meat quality parameters of pigs have been established. But not so many genes and the corresponding DNA markers, which in terms of their informativity and the strength of association with the traits, can be effectively used in practical selection.

The selection in pig breeding involves a set of measures that ensure the development of animal productivity improving the animal, herds and breeds. Effective breeding is not possible without involving new approaches that predict animal DNA genotyping by the chosen polymorhisms. Cathepsine F (CTSF) is the potential candidate for marker-assosiated selection, which directly participates in fat storing processes and meat qualities of pigs.
The genetic structure of such pig breeds as Ukrainian Large White, Poltava Meaty, Ukrainian Large Black and Mirgorods'ka for cathepsin F gene (CTSF g.22 G> C SNP) was determined, and basic population parameters were established. In all populations, the genetic marker was characterized by polymorphism with the predominance of the g.22C allele frequency. The level of informativity of CTSF g.22 G> C SNP was found at the optimal level for associative analysis ( $\mathrm{PIC}=0.358-0.375$ ), which allows to search for marker associations with traits of pig productivity in the studied subspecies.

In the subpopulation of Ukrainian Large White breed, the analysis of the genetic marker CTSF g.22 G> C SNP was studied by the following traits: the age for reaching the live weight of $100 \mathrm{~kg}$, the thickness of the backfat at the level of the 6th-7th rib, 10th ribs, in the sacrum area and the average daily weight gain. After the statistical analysis the tendency towards the association of the CTSF g.22 $\mathrm{G}>\mathrm{C}$ genetic marker with the age parameter for reaching the live weight of $100 \mathrm{~kg}(\mathrm{p}=0.07)$ was found.

The other studied populations of pig breeds can further be used for associative researches in order to find assosiations between the chosen genetical marker and meat and backfat quality parameters.

Key words: pigs, breeds, SNP, genetic structure, gene of cathepsin F. 